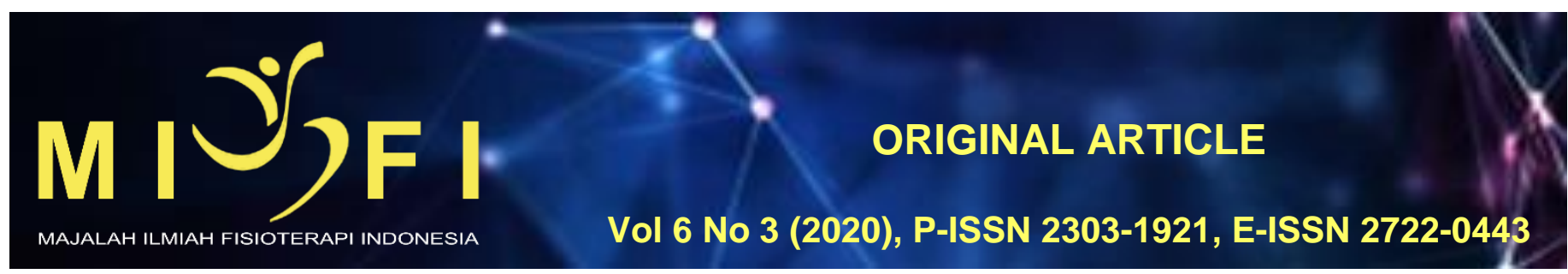

\title{
UJI VALIDITAS DAN RELIABILITAS ADAPTASI LINTAS BUDAYA KUESIONER NECK DISABILITY INDEX VERSI INDONESIA PADA MECHANICAL NECK PAIN
}

\author{
I Putu Mahendra Putra1, Made Hendra Satria Nugraha², Ni Wayan Tianing ${ }^{3}$, I Dewa Ayu Inten Dwi Primayanti ${ }^{4}$ \\ ${ }^{1}$ Program Studi Sarjana Fisioterapi dan Profesi Fisioterapi, Fakultas Kedokteran, Universitas Udayana, Denpasar, Bali \\ ${ }^{2}$ Departemen Fisioterapi, Fakultas Kedokteran Universitas Udayana, Denpasar, Bali \\ ${ }^{3}$ Departemen Biokimia, Fakultas Kedokteran Universitas Udayana, Denpasar, Bali \\ ${ }^{4}$ Departemen IImu Faal, Fakultas Kedokteran, Universitas Udayana, Denpasar, Bali \\ ivomahendra8@gmail.com
}

\begin{abstract}
ABSTRAK
Nyeri leher merupakan suatu kondisi kesehatan yang memiliki angka kejadian yang tinggi di populasi umum. Melakukan asesmen terhadap tanda dan gejala merupakan hal yang sangat penting dalam proses perencanaan dan evaluasi. Suatu alat ukur harus memenuhi unsur psikometrik dan mampu menyesuaikan dengan karakteristik sosial dan budaya setempat. Tujuan dari penelitian ini adalah untuk menghasilkan alat ukur kuesioner disabilitas Neck Disability Index versi Indonesia dengan metode adaptasi lintas budaya dengan nilai validitas dan reliabilitas yang tinggi. Penelitian ini merupakan penelitian observasional analitik, dimana tiap subjek diminta mengisi kuesioner dua kali dengan jarak waktu tujuh hari. Pengambilan sampel dilakukan dengan metode purposive sampling. Hasil analisis menggunakan pearson product moment didapatkan nilai $p$ sebesar $0.000(p<0.05)$, nilai $r_{\text {hitung }}>r_{\text {tabel }}$ dan nilai korelasi koefision diatas $0.61(0.61<r \leq 0.80)$. Hasil analisis menggunakan content validity index didapatkan nilai $\mathrm{I} / \mathrm{CVI}=1$ $(\mathrm{I} / \mathrm{CVI}>0.79), \mathrm{S}-\mathrm{CVI} /$ Ave $=1$ dan $\mathrm{S}-\mathrm{CVI} / \mathrm{UA}=1(\mathrm{~S}-\mathrm{CVI}>0.80)$, dan nilai $\mathrm{ACP}=97.67 \%(\mathrm{ACP}>0.90)$. Hasil analisis menggunakan cronbach's alpha didapatkan nilai $r$ sebesar 0.895 ( $0.81<r \leq 1.00$ ), dan dari hasil analisis interclass correlation coefficient menggunakan spearman correlation coefficient didapatkan nilai $r$ sebesar 0.859 ( $0.81<r \leq 1.00$ ). Berdasarkan hasil analisis, dapat disimpulkan bahwa adaptasi lintas budaya kuesioner neck disability index versi bahasa Indonesia memiliki nilai validitas dan reliabilitas yang tinggi.
\end{abstract}

Kata kunci: validitas, reliabilitas, kuesioner, neck disability index, mechanical neck pain.

\section{VALIDITY AND RELIABILITY TEST OF CROSS CULTURAL ADAPTATION OF NECK DISABILITY INDEX QUESTIONNAIRE IN INDONESIA VERSION ON MECHANICAL NECK PAIN}

\begin{abstract}
Neck pain is a health condition that has a high incidence in the general population. Assessing signs and symptoms is very important in the planning and evaluation process. A measuring instrument must meet the psychometric elements and be able to adjust to local social and cultural characteristics. The purpose of this study is to produce a measure of the Indonesian version of the Neck Disability Index questionnaire with cross-cultural adaptation methods with high values of validity and reliability. This research was an observational analytic study, where each subject was asked to fill out a questionnaire twice with a gap of seven days. Sampling was done by purposive sampling method. The analysis using Pearson product moment obtained $p$ value of $0,000(p<0.05), r$ count value $r$ table and correlation coefficient values above $0.61(0.61<r \leq 0.80)$. The results of the analysis using content validity index obtained I / CVI value $=1(\mathrm{I} / \mathrm{CVI}>0.79), \mathrm{S}-\mathrm{CVI} / \mathrm{Ave}=1$ and $\mathrm{S}-\mathrm{CVI} / \mathrm{UA}=1(\mathrm{~S}-\mathrm{CVI}>0.80)$, and $\mathrm{ACP}$ value $=97.67 \%(\mathrm{ACP}>0.90)$. The results of the analysis using Cronbach's alpha obtained an $r$ value of $0.895(0.81<r \leq 1.00)$, and from the results of the analysis of the interclass correlation coefficient using the Spearman correlation coefficient the $r$ value of $0.859(0.81$ $<r \leq 1.00$ ) was obtained. Based on the analysis results, it can be concluded that the cross-cultural adaptation of the Indonesian version of the neck disability index questionnaire has high validity and reliability values.
\end{abstract}

Keywords: validity, reliability, questionnaire, neck disability index, mechanical neck pain

\section{PENDAHULUAN}

Nyeri leher merupakan suatu kondisi kesehatan yang memiliki angka kejadian yang tinggi di populasi umum dan menyebabkan ketidakmampuan dalam melakukan aktivitas sehari-hari dan memerlukan biaya dalam penanganannya. Walaupun tidak mengancam nyawa, nyeri leher dapat memberikan efek negatif pada saat bekerja dan kualitas hidup seseorang ${ }^{[1,2]}$. Nyeri leher terjadi pada kurang lebih $67 \%$ pada orang dewasa dengan rentang umur 20 69 tahun ${ }^{[3]}$.

Mechanical neck pain atau disebut juga non spesifik neck pain, merujuk kepada nyeri leher yang disebabkan karena adanya lesi pada spine atau struktur penunjang leher, seperti minor strain dan sprain pada ligamen dan otot servikal, akibat dari suatu trauma, kesalahan postur, pekerjaan yang dapat menimbulkan strain ${ }^{[4,5]}$. Lesi pada zygapophyseal joint (sendi facet) di regio servikal dan spasme otot/muscle tignhtness di regio servikal juga dapat dikatakan sebagai mechanical neck pain ${ }^{[6]}$. 
Penanganan terhadap mechanical neck pain harus dilakukan secara efektif. Praktisi klinis juga harus mempertimbangkan aktivitas dan partisipasi dari pasien yang dipengaruhi oleh faktor kontekstual, baik secara internal (personal pasien) maupun eksternal (lingkungan pasien). Hal ini dapat memberikan pengaruh terhadap peningkatan hasil intervensi ${ }^{[7,8]}$.

Melakukan asesmen terhadap tanda dan gejala merupakan hal yang sangat penting dalam proses perencanaan dan evaluasi. Sehingga, dalam melakukan evaluasi, diperlukan alat ukur yang dapat memenuhi nilai standar internasional. Suatu alat ukur harus memenuhi unsur psikometrik dan mampu menyesuaikan dengan karakteristik sosial dan budaya setempat.

Neck Disability Index (NDI) merupakan satu satunya alat ukur berupa kuesioner yang mengevaluasi intensitas nyeri dan aktivitas sehari-hari dan mengukur tingkat keterbatasan dalam melakukan kegiatan sehari-hari[9]. NDI sering digunakan sebagai alat ukur untuk menilai dampak dari nyeri leher pada aktivitas fungsional pasien dan untuk mengukur hasil dalam praktik klinis dan penelitian. NDI memiliki 10 buah item pertanyaan yang menekankan pada nyeri dan aktivitas sehari-hari seperti intensitas nyeri, perawatan diri, mengangkat beban, membaca, sakit kepala, konsentrasi, bekerja, mengemudi, tidur, dan rekreasi[10,11]..

NDI memiliki instrumen psikometrik yang adekuat dalam bahasa Inggris dan beberapa bahasa lainnya, namun tidak dengan bahasa Indonesia. Sehingga, diperlukan sebuah studi adaptasi lintas budaya dan pengujian terhadap validitas dan realibilitas dari kuesioner tersebut. Adaptasi lintas budaya/ cross-cultural adaptation merupakan suatu proses memodifikasi suatu instrumen ke dalam sebuah versi yang berpatokan pada nilai sosial dan budaya, termasuk bahasa, tanpa merubah makna dari versi asli instrumen tersebut.

Validasi terhadap hasil translasi diperlukan untuk memastikan kesesuaian alat ukur dengan kondisi setempat. Adanya penyesuaian dalam konteks dan isi kuesioner ini terhadap latar belakang sosial dan budaya di Indonesia, diharapkan pasien dapat memahami dan mengerti akan kondisinya. Selain itu kuesioner ini juga dapat digunakan oleh tenaga medis maupun peneliti untuk keperluan penelitian dan praktik klinis.

\section{METODE}

Peneliti menggunakan metode penelitian observasional analitik pada penelitian ini. Populasi terjangkau dalam penelitian ini adalah individu yang mengeluhkan atau terdiagnosis secara klinis mechanical neck pain di praktik mandiri fisioterapi di kota Denpasar dan Badung. Sampel dalam penelitian ini adalah individu yang memenuhi kriteria-kriteria seperti pasien dengan diagnosis mechanical neck pain, dapat berkomunikasi secara lisan maupun tulisan dalam bahasa Indonesia, bersedia mengisi informed consent, bersedia mengisi kuesioner sebanyak 2 kali. Pengisian pertama dilakukan sebelum mendapat intervensi fisioterapi, dan pengisian kedua dilakukan setelah 7 hari dari pengisian pertama setelah diberikan intervensi oleh fisioterapis berdasarkan pertimbangan klinis. Kriteria eksklusi dalam penelitian ini adalah Pasien dengan myelopathy pasien dengan neoplasma, memiliki riwayat fraktur di regio leher, memiliki penyakit sistemik, dan terdapat tanda-tanda patologi neurologis. Teknik pengambilan sampel yang digunakan dalam penelitian ini adalah teknik Purposive Sampling Besar sampel yang ditentukan untuk penelitian ini adalah 50 subjek. Sampel diminta untuk mengisi kuesioner NDI sebanyak 2 kali dengan selang waktu pengisian kuesioner 7 hari. Pengisian pertama dilakukan sebelum mendapat intervensi fisioterapi, dan pengisian kedua dilakukan setelah 7 hari dari pengisian pertama. Intervensi yang diberikan adalah intervensi standar untuk kasus mechanical neck pain. Tidak ada intervensi khusus yang diberikan kepada subjek penelitian.

Proses translasi kuesioner dilakukan dalam tiga tahap, yaitu forward translation, backward translation, dan sintesis hasil terjemahan. Forward translation merupakan proses yang dilakukan untuk mengubah kuesioner berbahasa Inggris menjadi bahasa target yaitu bahasa Indonesia .Proses forward translation dilakukan dengan melibatkan dua warga negara asing dengan bahasa ibu bahasa Inggris dan telah menguasai bahasa Indonesia. Keduanya merupakan tenaga pengajar disalah satu sekolah ternama di Bali dan telah tinggal di Indonesia selama beberapa tahun. Backward translation merupakan proses translasi hasil forward translation kembali ke bahasa awalnya, yaitu bahasa Inggris. Proses Backward translation dilakukan dengan melibatkan dua orang berkewarganegaraan Indonesia yang menguasai bahasa Inggris baik secara lisan maupun tulisan. Keduanya merupakan lulusan Sarjana Sastra Inggris disalah satu kampus ternama di Bali dan telah berpengalaman dalam hal translasi. Proses sintesis hasil terjemahan dilakukan dengan melibatkan tiga orang asesor yang memahami kedua bahasa tersebut serta memahami karakteristik kasus mechanical neck pain.

Penelitian ini menilai construct validity, conten validity, internal consistency dan test-retest reliability. Construct validity diuji menggunakan pearson product moment. Content validity dinilai menggunakan content validity index (CVI).Content validity dinilai oleh 3 orang ahli, dimana menilai 4 aspek penilaian, seperti kejelasan, relevansi, ambiguitas, dan kesederhanaan. Internal consistency diuji menggunakan cronbach's alpha, dan test-retest reliability diuji menggunakan interclass correlation coefficient.

\section{HASIL PENELITIAN}

Karakteristik sampel penelitian dianalisa berdasarkan usia dan jenis kelamin dari subjek seperti yang dijabarkan pada Tabel 1.

Tabel 1. Karakteristik Subjek Penelitian

\begin{tabular}{ll}
\hline \multicolumn{1}{c}{ Karakteristik } & $\mathrm{N}(f)$ \\
\hline $\begin{array}{l}\text { Jenis Kelamin } \\
\text { Laki-laki } \\
\text { Perempuan }\end{array}$ & $25(50)$ \\
Usia (tahun) & $25(50)$ \\
\hline
\end{tabular}




\begin{tabular}{lc}
\hline Mean \pm SD & $49.34 \pm 12.130$ \\
Hasil Pengukuran Tingkat Disabilitas & \\
Pengukuran 1 & \\
Tidak Ada Disabilitas $(0-4)$ & 8 \\
Disabilitas Ringan $(5-14)$ & 28 \\
Disabilitas Sedang $(15-24)$ & 12 \\
Disabilitas Berat $(25-34)$ & 2 \\
Disabilitas Komplit $(>34)$ & 0 \\
Pengukuran 2 & 18 \\
Tidak Ada Disabilitas $(0-4)$ & 29 \\
Disabilitas Ringan $(5-14)$ & 3 \\
Disabilitas Sedang $(15-24)$ & 0 \\
Disabilitas Berat $(25-34)$ & 0 \\
Disabilitas Komplit $(>34)$ & \\
\hline
\end{tabular}

Data yang diperoleh dari 50 pasien nyeri leher mekanik dengan usia rata-rata dan standar deviasi 49,34 \pm 12,130 tahun dihitung menggunakan SPSS versi 16. Kelompok penelitian terdiri dari 25 pria dan 25 wanita. Terdapat penurunan pada hasil pengukuran disabilitas antara pengukuran pertama dengan pengukuran kedua.

Hasil penilaian uji content validity dapat dilihat pada Tabel 2.

Tabel 2. Hasil Uji Content Validity Index (CVI)

\begin{tabular}{ccccccc}
\hline Item & $\begin{array}{c}\text { Relevan } \\
\text { (nilai 3 atau 4) }\end{array}$ & $\begin{array}{c}\text { Tidak Relevan } \\
\text { (nilai 1 atau 2) }\end{array}$ & I-CVIs & S-CVI/Ave & S-CVI/UA & Interpretasi \\
\hline 1 & 3 & 0 & 1 & 1 & 1 & Tepat \\
2 & 3 & 0 & 1 & 1 & 1 & Tepat \\
3 & 3 & 0 & 1 & 1 & 1 & Tepat \\
4 & 3 & 0 & 1 & 1 & 1 & Tepat \\
5 & 3 & 0 & 1 & 1 & 1 & Tepat \\
6 & 3 & 0 & 1 & 1 & 1 & Tepat \\
7 & 3 & 0 & 1 & 1 & 1 & Tepat \\
8 & 3 & 0 & 1 & 1 & 1 & Tepat \\
9 & 3 & 0 & 1 & 1 & 1 & Tepat \\
10 & 3 & 0 & 1 & 1 & 1 & Tepat \\
\hline
\end{tabular}

Berdasarkan Tabel 2. didapatkan hasil analisis data nilai rata-rata I-CVIs dari 3 orang asesor adalah 1. Hasil analisa dari I-CVIs diatas 0.79 , jadi dapat disimpulkan bahwa seluruh item pertanyaan bernilai baik sehingga butir pertanyaan tidak perlu dieliminasi ataupun direvisi. Nilai S-CVI/Ave dari 3 orang asesor adalah 1 dan nilai S-CVI/UA dari 3 orang asesor adalah 1 . Karena nilai S-CVI diatas 0.80 , maka seluruh item pertanyaan dapat diterima ${ }^{[12]}$.

Pada tabel 3 disajikan average congruency percentage - ACP (persentase kongruensirata-rata).

Tabel 3. Hasil Average Congruency Percentage

\begin{tabular}{ccccc}
\hline & Asesor 1 & Asesor 2 & Asesor 3 & ACP \\
\hline Total penilaian item construct & $100 \%$ & $99.68 \%$ & $93.33 \%$ & $97.67 \%$ \\
\hline
\end{tabular}

Berdasarkan Tabel 3. didapatkan hasil analisis nilai ACP dari ketiga asesor adalah $97.67 \%$. Karena nilai ACP adalah diatas 0.90 maka instrumen dapat diterima ${ }^{[13]}$.

Pada tabel 4. disajikan hasil uji validitas menggunakan Pearson product moment

Tabel 4. Hasil Uji Validitas Kuesioner Modifikasi NDI Versi Indonesia

\begin{tabular}{clcccc}
\hline No & Pertanyaan & r hasil & $\mathbf{r}$ tabel & Nilai $\mathbf{p}$ & Kesimpulan \\
\hline 1 & Intensitas nyeri & 0.722 & & 0.000 & \\
2 & Perawatan diri & 0.799 & & 0.000 & \\
3 & Mengangkat & 0.645 & & 0.000 & \\
4 & Membaca & 0.776 & & 0.000 & \\
5 & Sakit kepala & 0.736 & 0.2787 & 0.000 & Valid \\
6 & Konsentrasi & 0.764 & & 0.000 & \\
7 & Bekerja & 0.728 & & 0.000 & \\
8 & Menyetir & 0.690 & 0.000 & \\
9 & Tidur & 0.617 & 0.000 & \\
10 & Rekreasi & 0.751 & 0.000 & \\
\hline
\end{tabular}

Pada penilaian construct validity, nilai $r$ tabel yang ditetapkan untuk jumlah sampel 50 adalah 0.2787 . Pada uji construct validity didapatkan nilai $(\mathrm{p}<0.05)$ dengan $\mathrm{r}_{\mathrm{itung}}>\mathrm{r}$ tabel pada seluruh item pertanyaan kuesioner. Jadi dapat disimpulkan bahwa seluruh pertanyaan valid. Hasil construct validity untuk kuesioner modifikasi NDI versi Indonesia memiliki validitas yang tinggi $(0.61<r \leq 0.80)$.

Hasil uji reliabilitas (internal consistency) menggunakan Cronbach's alpha disajikan pada tabel 5 dan tabel 6 . 
Tabel 5. Hasil Uji Reliabilitas Kuesioner Modifikasi NDI versi Indonesia $\mathbf{N}$ item Koefisien reliabilitas

Tabel 6. Hasil Uji Cronbach's Alpha Item Kuesioner Modifikasi NDI Versi Indonesia

\begin{tabular}{cc}
\hline Item & Nilai Cronbach's Alpha \\
\hline Pertanyaan 1 & 0.884 \\
Pertanyaan 2 & 0.877 \\
Pertanyaan 3 & 0.889 \\
Pertanyaan 4 & 0.879 \\
Pertanyaan 5 & 0.884 \\
Pertanyaan 6 & 0.880 \\
Pertanyaan 7 & 0.883 \\
Pertanyaan 8 & 0.887 \\
Pertanyaan 9 & 0.896 \\
Pertanyaan 10 & 0.882 \\
\hline
\end{tabular}

Berdasarkan Tabel 5.hasil uji reliabilitas dari kuesioner NDI versi Indonesia adalah 0.895 , maka semua item pertanyaan pada kuesioner NDI versi Indonesia adalah reliabel karena memiliki nilai diatas 0.70[13]. Dan nilai dari internal consistency didapatkan hasil cronbach's alpha 0.895 atau kesepuluh item pertanyaan adalah reliabel (Tabel 6). Hasil internal consistency juga menunjukan nilai reliabilitas sangat tinggi $(0.81<r \leq 1.00)$.

Pada tabel 7. disajikan hasil uji test-retest reliability menggunakan interclass correlation coefficient.

Tabel 7. Hasil Uji Reliabilitas menggunakan Interclass Correlation Coefficient

\begin{tabular}{|c|c|c|c|c|c|c|c|}
\hline & \multirow{2}{*}{ Interclass Correlation } & \multicolumn{2}{|c|}{ 95\% Confidence Interval } & \multicolumn{4}{|c|}{ F Test with True Value 0} \\
\hline & & Lower Bound & Upper Bound & Value & df1 & df2 & Sig \\
\hline Single Measures & 0.859 & 0.764 & 0.917 & 13.180 & 49 & 49 & 0.000 \\
\hline Average Measures & 0.924 & 0.866 & 0.957 & 13.180 & 49 & 49 & 0.000 \\
\hline
\end{tabular}

Berdasarkan Tabel 7 menunjukan output Interclass Correlation Coefficient untuk mengukur test-retest reliability yang menunjukan nilai reliabilitas yang cukup memuaskan, yaitu 0.859 . Hasil test-retest reliability menunjukan nilai reliabilitas sangat tinggi $(0.81<r \leq 1.00)$.

\section{DISKUSI}

Menguji validitas translasi perlu dilakukan dengan menggunakan konsep adaptasi lintas budaya. Adaptasi lintas budaya/ cross-cultural adaptation merupakan suatu proses memodifikasi suatu instrumen ke dalam sebuah versi yang berpatokan pada nilai sosial dan budaya, termasuk bahasa, tanpa merubah makna dari versi asli instrumen tersebut.

Terdapat beberapa proses penting dalam adaptasi lintas budaya,salah satunya adalah proses translasi bahasa ${ }^{[14]}$. Validasi terhadap hasil translasi diperlukan untuk memastikan kesesuaian alat ukur dengan kondisi setempat. Hal ini disebabkan karena versi asli dan modifikasi dari kuesioner tidak dapat diaplikasikan karena dalam beberapa poin terdapat perbedaan dari segi budaya dan latar belakang sosial serta masyarakat Indonesia yang masih asing atau tidak familiar terhadap alat ukur ini. Selanjutnya, versi adaptasi akan melalui proses evaluasi berdasarkan pengukuran mendasar seperti validitas dan reliabilitas.

Hal yang dievaluasi dalam penelitian ini adalah construct validity, content validity, internal consistency dan testretest reliability. Construct validity merupakan jenis validitas yang membahas mengenai sejauh mana butir-butir suatu tes atau instrumen dapat mengukur apa yang memang akan diukur sesuai dengan definisi konseptual atau konsep khusus yang sudah ditetapkan[15]. Construct validity dinilai dengan menggunakan Pearson product moment. Pada penilaian construct validity, nilai $r$ tabel yang ditetapkan untuk jumlah sampel 50 adalah 0.2787 . Pada uji construct validity didapatkan nilai $(\mathrm{p}<0.05)$ dengan $r_{\text {hitung }}>r_{\text {tabel }}$ pada seluruh item pertanyaan kuesioner. Jadi dapat disimpulkan bahwa seluruh pertanyaan valid. Hasil construct validity untuk kuesioner modifikasi NDI versi Indonesia memiliki validitas yang tinggi $(0.61<r \leq 0.80)$.

Content validity dinilai menggunakan content validity index (CVI). CVI biasanya digunakan untuk menilai validitas suatu instrumen dengan menggunakan pendapat pakar atau ahli pada bidangnya. Pakar atau ahli akan diminta untuk menilai item suatu instrumen berdasarkan pendapat dan pandangan mereka sendiri. Pengukuran CVI bisa dilakukan dengan memberikan skor pada tiap item instrumen dengan nilai skala umumnya 1-4 dengan interpretasi 1: tidak relevan, 2 : sedikit relevan, 3 : cukup relevan, dan 4 : relevan [12]. CVI juga dapat diukur dengan 4 pertanyaan, yaitu relevansi, kejelasan, kesederhanaan dan ambiguitas, dimana masing-masing item pertanyaan tersebut diberi skor 1-4 dengan interpretasi 1 : paling buruk dan 4 : paling baik ${ }^{[16]}$.

Untuk mengevaluasi content validity menggunakan CVI, dapat dilakukan dengan dua cara, yaitu menilai kesepakatan ahli dalam tingkat item menggunakan item-level content validity index (I-CVI) dan menilai kesepakatan ahli secara keseluruhan menggunakan scale-level content validity index (S-CVI). Untuk mengukur S-CVI terdapat dua metode, yaitu universal agreement among experts (S-CVI/UA) dan averages the item-level (S-CVI/Ave). S-CVI/UA dihitung dengan menjumlah item yang relevan dari penilaian content experts ( yang mendapat skor 3 atau 4) dibagi dengan jumlah seluruh pertanyaan. S-CVI/Ave dihitung dengan cara menjumlah total I-CVIs dan dibagi dengan jumlah item pertanyaan. Average congruency percentage (ACP) merupakan persentasi kongruensi rata-rata yang digunakan untuk menilai face dan content validity. Nilai ACP yang disarankan minimal 0.90[13] .

Hasil analisa dari I-CVIs diatas 0.79 , jadi dapat disimpulkan bahwa seluruh item pertanyaan bernilai baik sehingga butir pertanyaan tidak perlu dieliminasi ataupun direvisi. Nilai S-CVI/Ave dari 3 orang asesor adalah 1 dan nilai S- 
CVI/UA dari 3 orang asesor adalah 1. Karena nilai S-CVI diatas 0.80, maka seluruh item pertanyaan dapat diterima. Hasil analisis nilai ACP dari ketiga asesor adalah 97.67\%. Karena nilai ACP adalah diatas 0.90 maka instrumen dapat diterima[12,13].

Internal-consistency reliability adalah pengukuran reliabilitas yang digunakan untuk mengevaluasi sejauh mana berbagai jenis item tes yang menilai konstruksi atau karakteristik yang sama menghasilkan hasil yang relatif sama ${ }^{2,17]}$

. Uji reliabilitas dengan menggunakan Cronbach alpha untuk mengukur internal consistency. Berdasarkan Tabel 5 hasil reliabilitas dari kuesioner NDI versi Indonesia adalah 0.895 , maka semua item pertanyaan pada kuesioner NDI versi Indonesia adalah reliabel karena memiliki nilai diatas 0.70 . Dan nilai dari internal consistency didapatkan hasil cronbach's alpha 0.895 atau kesepuluh item pertanyaan adalah reliabel (Tabel 6). Hasil internal consistency juga menunjukan nilai reliabilitas sangat tinggi $(0.81<r \leq 1.00)$.

Test-retest reliability adalah jenis ukuran reliabilitas yang didapatkan dengan cara mengelakukan tes yang sama sebanyak dua kali dengan rentang waktu mulai dari beberapa minggu hingga bulan pada suatu kelompok subjek yang sama[17,18]. Interclass correlation coefficient (Spearman's correlation coefficient) digunakan untuk mengukur test-retest reliability. Berdasarkan Tabel 7 menunjukan output Interclass Correlation Coefficient untuk mengukur test-retest reliability yang menunjukan nilai reliabilitas yang cukup memuaskan, yaitu 0.859 . Hasil test-retest reliability menunjukan nilai reliabilitas sangat tinggi $(0.81<r \leq 1.00)$.

Hasil pengukuran aspek psikometri yang dilakukan pada penelitian ini menunjukan hasil bahwa seluruh item pertayaan yang terdiri dari 10 item adalah valid. Dari aspek reliabilitas juga menunjukan nilai yang tinggi. Beberapa penelitian lain yang telah dilakukan di negara lain dengan metode adaptasi lintas budaya seperti versi bahasa Jepang, Portugis, Spanyol, Swedia, Arab, Katalan, China, Finlandia, Prancis, Yunani, Iran, Italia, Korea, Brazil, Hindi, Polandia, Thailand, dan Turki juga menunjukan hasil yang relevan ${ }^{[1,19,20]}$. Hasil adaptasi lintas budaya kuesioner NDI versi Indonesia ini secara klinis dapat diindikasikan sebagai salah satu alat ukur dan alat evaluasi yang valid dan reliabel.

\section{SIMPULAN}

Nilai validitas dan reliabilitas dari kuesioner modifikasi neck disability index versi bahasa Indonesia memiliki nilai validitas dan reliabilitas yang tinggi pada mechanical neck pain. Kuesioner modifikasi neck disability index versi Indonesia dapat digunakan sebagai alat ukur dan evaluasi yang valid dan reliabel pada keluhan mechanical neck pain.

\section{DAFTAR PUSTAKA}

1. Yao, M., Sun, Y., Cao, Z., Dun, R., Yang, L., Zhang, B., Jiang, H., Wang, Y., Cui, X., 2015. A Systematic Review of Cross-Cultural Adaptation of the Neck Disability Index. Spine, 40(7), pp. 80-90.

2. Shaheen, A. O. M. V. H., 2013. Cross-cultural Adaptation, Reliability, and Validity of the Arabic Version of Neck Disability Index in Patients With Neck Pain. Spine, 38(10), pp. 609-615.

3. Wadee, A. N., 2017. Efficacy of Muscle Energy Technique versus Myofascial Relese in MAnagement of Patients with Cervical Myofascial Pain. International Journal of ChemTech Research, 10(2), pp. 68-76.

4. Juliastuti, 2017. Perbedaan Pengaruh Pemberian Auto Stretching dan Kinesio Taping Terhadap Penurunan Nyeri Pada Sindroma Nyeri servikal et causa Mechanical Neck Pain. 5(2), pp. 432-444.

5. Cohen, S. P., 2015. Epidemiology, Diagnosis, and Treatment of Neck Pain. Mayo Clin Proc, 90(2), pp. $284-299$.

6. Sudaryanto, Sutjana, D. \& Irfan, M., 2013. Pemberian Teknik Mulligan dan SOft Tissue Mobilization Lebih Baik Daripada Hanya Soft Tissue Mobilization Dalam Meningkatkan Lingkup Gerak Sendi Ekstensi, Rotasi, dan Lateral Fleksi Cervical Pada Mechanical Neck Pain. Sport Fitness Journal, 1(2), pp. 54-69.

7. Blanpied, P. R., Gross, A.R., Elliot, J.M., Devaney, L.L., Cleveley, D., Walton, D.M., Sparks, C., Robertson, E.K., 2017. Clinical Practice Guidelines Linked to the International Classification of Functioning, Disability, and Health From the Orthopaedic Section of the Americans Physical Therapy Association. Journal of Orthopaedic \& Sports Physical Therapy, 47(7), pp. 1-83.

8. WHO, 2001. International Classification of Functioning, Disability and Health : ICF. Geneva, Switzerland: s.n.

9. Kamper, S. J., Grootjans, S.J.M., Michaleff, Z.A., Maher, C.J., McAuley, J.H., Sterling, M., 2014. Measuring Pain Intensity in Patients with Neck Pain: Does It Matter Hw You Do It?. World Institute of Pain, pp. 1-9.

10. Vernon, H. \& Mior, S., 1991. The Neck Disability Index: A Study of Reliability and Validity. Journal of Manipulative and Physiological Therapeutics, Volume 14, pp. 409-415.

11. Kaka, B., Ogwumika, O.O., Vernon, H., Adeniyi, A.F., Ogunlade, A.O., 2016. Croos-Cultural Adaptatin, Validity and Reliability of the Hausa Version of the Neck Disability Index Questionnaire. International Journal of Therapy and Rehabilitation, 23(8), pp. 380-385.

12. Polit, D. F. \& Beck, C. T., 2006. The Content Validity Index: Are You Sure You Know What's Being Reported? Critique and Recommendations. Research in Nursing \& Health, Volume 29, p. 489-497.

13. Nugraha, M. H. S., Antari, N. K. A. J. \& Saraswati, N. L. P. G. K., 2019. Uji Validitas dan Reliabilitas Adaptasi Lintas Budaya Modifikasi Northwick Park Neck Pain Questionnaire Versi Indonesia Pada Mechanical Neck Pain. Majalah IImiah Fisioterapi Indonesia, 7(3), pp. 1-4.

14. Gjersing, L., Caplehorn, J. R. \& Clausen, T., 2010. Cross-cultural adaptation of research instruments: language, setting, time and statistical considerations. BMC Medical Research Methodology, 10(13), pp. 1-10.

15. Matondang, Z., 2009. Validitas dan Reliabilitas Suatu Instrumen Penelitian. Jurnal Tabularasa PPS Unimed, 6(1), pp. 87-97.

16. Yaghmale, F., 2003. Content validity and its estimation. Journal of Medical Education, 3(1), pp. 25-27.

17. Trouli, M. N., Vernon, H.T., Kakavelakis, K.N., Antonopoulou, M.P., Paganas, A.N., Lionis, C.D., 2008. Translation of the Neck Disability Index and Validation of the Greek Version in a Sample of Neck Pain Patients. BMC Musculoskeletas Disorders, 9(106). 
18. Mohajan, H., 2017. Two Criteria for Good Measurements in Research: Validity and Reliability. Annals of Spiru Haret University, 17(3), pp. 28-82.

19. Cramer, H., Lauche, R., Langhorst, J., Dobos, G.J., Michalsen, A., 2014. Validation of the German Version of the Neck Disability Index (NDI). BMC Musculoskeletal Disorders, 15(91).

20. Kamdar, K. \& Kakkad, A., 2014. A STudy to Find Out Test Retesr Reliability and Validity of Gujarati Version of Neck Disability Index AMong Gujarati Speaking Indian Population With Neck Pain-A Correlation Study. Indian Journal of Pyshical Therapy, 2(2), pp. 43-48. 